\title{
Elementarne pojęcia, problemy i zagadnienia socjologii religii, socjologii moralności, socjologii wartości i norm w ujęciu ks. prof. Janusza Mariańskiego
}

Janusz Mariański, Aforyzmy, myśli, sentencje i refleksje socjologiczne (Religia Kośció - moralność - wartości - godność ludzka - sens życia), Wyższa Szkoła Nauk Społecznych z siedzibą w Lublinie, Lublin 2020, ss. 410.

S siądz Profesor Janusz Mariański jest autorem kilkudziesięciu zwartych monografii i ponad 1500 artykułów i rozpraw fragmentarycznych z zakresu socjologii religii i religijności, socjologii Kościoła i parafii, socjologii moralności, socjologii wartości i norm, a także godności ludzkiej, sensu życia i śmierci czy socjologii rodziny i wychowania religijno-moralnego, religijności i moralności młodzieży szkół średnich i akademickiej oraz duchowości, które opublikował w ciągu wieloletniej twórczej pracy naukowej. U podłoża tych publikacji zawsze znajdują się trafne i głębokie założenia teoretyczne oraz wyniki wzorcowo metodologicznie zaplanowanych i zrealizowanych badań socjologicznych. Publikacje te stanowią od zawsze, z jednej strony, wzór do naśladowania dla innych socjologów, zwłaszcza młodszej generacji, w zakresie konstruowania własnych komunikatów badawczych i analiz empirycznych, zaś z drugiej strony, są one głębokim źródłem naukowej wiedzy socjologicznej z zakresu socjologii religii i socjologii moralności oraz zagadnień 
z nimi wprost związanych czy z nich pochodzących. Śledząc publikacje polskich socjologów religii i moralności, rodziny i młodzieży, wartości i norm czy sensu życia i śmierci, nietrudno dostrzec w nich odniesienia do publikacji ks. prof. Janusza Mariańskiego, jak i cytowania wyników Jego badań naukowych z tych dziedzin wiedzy socjologicznej. Prace te w wymiarze metodologicznym i merytorycznym są bardzo ważne i znaczące w polskiej socjologii religii i socjologii moralności, odgrywają rolę zasadniczą w ich rozwoju i wskazywaniu perspektywicznych pól badawczych i ujęć teoretycznych.

Liczne spojrzenia teoretyczne, refleksje i konstatacje czy konstrukcje pojęciowe spotykane w Jego publikacjach naukowych, zwłaszcza w książkach, są do pewnego stopnia odrębnymi dziełami myślowymi (pomysłami), nadającymi tym opracowaniom wartość poznawczą i zachęcającymi czytelników do dogłębnej ich lektury, do zapamiętania i zastosowania we własnych ich publikacjach. Znaczenie i celowość tych myśli i refleksji naukowych dostrzegł i docenił sam ks. prof. Janusz Mariański i postanowił wyodrębnić je z treści wielu swoich publikacji i ukazać w nowej książce pod wyżej podanym tytułem. Co składa się na treść tej oryginalnej w swej istocie książki, jaka jest jej struktura i jakie jest (może być) jej przeznaczenie?

Publikacja ta obejmuje swoim zasięgiem problematykę religii, Kościoła, moralności, wartości, godności ludzkiej i sensu życia oraz śmierci i duchowości. Tytuł książki jest dość „zagadkowy” i może sugerować czytelnikowi różnorodne skojarzenia związane z treścią tych określeń, jak i pytanie, czy Autor sam napisał te aforyzmy i sentencje socjologiczne? A także pytanie o naukowy profil samej książki. Obawy te rozwiewa już autor przedmowy do tej książki, prof. KUL dr hab. Jan Szymczyk, w której zaznacza, że „Autor, parafrazując myśl Stanisława Jerzego Leca, stwierdza, że nie pisze aforyzmów, fraszek, sentencji itp., ale »tylko piszę siebie, swój naukowy pamiętnik «. Prezentowane teksty raczej nie mają charakteru aforyzmów w ich klasycznej formie (zwięźle sformułowane, często jednozdaniowe), lecz są to rozbudowane myśli i refleksje. Tym samym nawiązują one do aforystyki uprawianej w tradycji niemieckiej jako wypowiedzi wielozdaniowych, skupionych na konkretnym problemie, układających się w pewne ciągi i dyskursy myślowe. Autor rzeczonej pracy jako dobrze przygotowany przewodnik zabiera nas w podróż do destynacji stanowiących przedmiot Jego naukowych zainteresowań. Doświadczamy podczas tej wyprawy-lektury omawianej książki gruntownego znawstwa przedmiotu ze strony Księdza Profesora. Ocena ta w szczególny sposób odnosi się do takich dyscyplin, jak: socjologia religii, socjologia moralności, socjologia wartości i norm. [...] W prezentowanej pracy mamy do czynienia z treściami »wydobytymi « z dorobku naukowego Księdza Profesora, czyli z tego, co zostało zawarte w Jego 60 książkach i w setkach artykułów. Aforyzmy, myśli i sentencje Autora zapraszają - z perspektywy socjologii - do podążania w stronę świata religii, moralności i wartości w zmieniającym się ustawicznie społeczeństwie. [...] Autor przy pomocy wybranych metod i form wypowiedzi objaśnia w sposób 
klarowny pojęcia używane w dyskursie socjologicznym. Aplikowane sentencje czy aforyzmy pomagają Księdzu Mariańskiemu w przemyśleniach nad złożoną rzeczywistością religijną czy moralną. [...] Ten uporządkowany zbiór aforyzmów, sentencji, maksym i złotych myśli lubelskiego socjologa obejmuje tematykę dosyć obszerną, ale skoncentrowaną na ważnych kwestiach socjologicznych i nierzadko filozoficznych (np. sens życia, zjawisko śmierci). Dlatego wiele refleksji Autora można uznać za pomocne w budowie życiowej mądrości potencjalnego Czytelnika. [...] Aforyzmy czy sentencje Autora nie są tylko czczą zabawą intelektualną, ale jawią się jako narzędzie wyrazu myśli o poważnym i głębokim charakterze. Socjologiczne refleksje Księdza Mariańskiego nie tylko uczą, ale zachęcają czy wręcz prowokują do dalszych przemyśleń o charakterze epistemologicznym, moralnym, aksjologicznym itp.” (ss. 7-9).

We własnym wstępie do książki ks. prof. Janusz Mariański również jasno zaznacza, że „Z opisanych sentencji, myśli i aforyzmów wyłania się mój pogląd na socjologię religii i socjologię moralności oraz sposób uprawiania tych dwóch subdyscyplin socjologicznych. Aforyzmy, sentencje, maksymy, myśli i refleksje przywoływane w tym opracowaniu mają do pewnego stopnia charakter instruktażowy, o niezbyt dużej sile ekspresji. Może być to opracowanie potraktowane jako quasi-minipodręcznik socjologii religii i socjologii moralności. Bez penetrowania wielu moich książek i artykułów, czy szerzej dzieł z polskiej literatury socjologicznej, tu można zapoznać się z podstawową wiedzą socjologiczną na ten temat” (s. 11). Następnie Autor przytacza różne ujęcia pojęcia aforyzmu i omawia charakterystykę aforyzmów definiowanych przez ich znawców i badaczy. Eksponując własne podejście do pojęcia ,aforyzm” wskazanego w tytule książki, zaznacza, że „Teksty zamieszczone w tej książeczce - w świetle tych kryteriów - aforyzmami nie są. Są to raczej myśli, sentencje, maksymy, definicje, sądy wartościujące, pouczenia, krótkie konstatacje itp., wyrwane z szerszego kontekstu treściowego (fragmenty szerszych całości), aforyzmopodobne teksty czy o aforystycznej proweniencji” (ss. 12-13). Dalej Autor pisze, że „Niektóre z zamieszczonych tu tekstów mają charakter sentencji” (s. 14) i ukazuje różne ujęcia treści tego pojęcia. „Jeszcze inne teksty zamieszczone w tej książce mają charakter złotych myśli czy pouczających maksym. Złota myśl to »zwięzłe sformułowanie, zaczerpnięte najczęściej ze znanych utworów, o charakterze sentencji czy aforyzmów, zawierające jakieś prawdy moralne lub praktyczne (prakseologiczne)« (cyt. za: Kudra, 2015, s. 44-45) ${ }^{1}$. Złote myśli to cenne, trafne i mądre sądy, sformułowania, przysłowia, maksymy, powiedzenia. [...] Sentencje, myśli, aforyzmy, refleksje, maksymy nie tylko uczą, ale prowokują do dalszych przemyśleń o charakterze epistemologicznym, estetycznym, moralnym, obyczajowym, aksjologicznym itp.” (ss. 15-16).

${ }^{1}$ B. Kudra, Aforyzm w tekście naukowym - na przykładzie prac Michaela Fleischera i Niklasa Luhmanna, w: Aforyzm europejski. Studia i szkice, red. A. Jarzyna, J. Jęcz, M. Junkiert, K. Kuczyńska-Koschany, Pasaże, Kraków 2015, ss. 44-45. 
Rekomendując własną książkę, ks. prof. Janusz Mariański pisze, że „Niniejsza książka ma za zadanie przedstawić Czytelnikowi w zwięzłej formie, czym jest socjologia religii i socjologia moralności oraz socjologia wartości i norm, jak ją prezentuję w szerokiej formie w swoich ponad 60 książkach i w setkach artykułów. Wybrane teksty (wypisy) zostały zgrupowane w szesnastu rozdziałach: I - Socjologia religii jako nauka o faktach religijnych (s. 23-36); II - Socjologia moralności jako nauka o faktach moralnych (s. 37-60); III - Socjologia wartości i norm (s. 61-80); IV - Sekularyzacja i desekularyzacja w społeczeństwie ponowoczesnym (s. 81-108); V - Nowa duchowość z perspektywy socjologicznej (s. 109-130); VI - Religia i religijność - aspekty socjologiczne (s. 131-154); VII - Wiara i wierzenia - ujęcie socjologiczne (s. 155-178); VIII - Praktyki religijne w procesie przemian (s. 179-198); IX - Parafia w kontekście społecznym (s. 199-222); X Kościół katolicki w kontekście społecznym (s. 223-242); XI - Moralność religijna w uwarunkowaniach społecznych (s. 243-268); XII - Godność ludzka jako wartość społeczno-moralna (s. 269-290); XIII - Socjologia a sens życia, cierpienia i śmierci (s. 291-322); XIV - Wychowanie religijno-moralne (s. 323-340); XV - Przyszłość religii i Kościoła - kontekst socjologiczny (s. 343-358); XVI - Varia (s. 359-366)" (ss. 18-19).

W podsumowaniu tych myśli ks. prof. Janusz Mariański zaznacza, że „Wybrane teksty rzadko mają charakter aforyzmów w ich klasycznej formie (zwięźle sformułowane, często jednozdaniowe), lecz raczej rozbudowane myśli i refleksje, wykraczające znacznie poza to, co określa się jako definicję zjawiska, sytuacji, stanu rzeczy itp. Są to wypowiedzi wielozdaniowe, skupione na konkretnym problemie, ale układające się w pewne ciągi i dyskursy myślowe. Są to więc bardziej myśli, konstatacje i sentencje niż aforyzmy socjologiczne. Treści te są wydobyte z szerszego kontekstu. W istocie są to najczęściej teksty wybrane z większych całości, zawierające w skrótowej formie opisy szerszych kwestii, pełniące w pewnym sensie rolę słowniczka pojęć podstawowych socjologii religii, socjologii moralności oraz socjologii wartości i norm, swoistych opinii aforyzujących, myśli mniej lub bardziej aforyzujących, często będących skrótowo wyrażonymi myślami czy sentencjami. W sensie ścisłym są to wypisy z moich książek, artykułów naukowych i popularno-naukowych” (ss. 19-20). Kontynuując tę myśl Autora, można pójść za Janem Szczepańskim² i powiedzieć, że recenzowana książka ks. prof. Janusza Mariańskiego mówi o elementarnych pojęciach, problemach i zagadnieniach socjologii religii i religijności, socjologii moralności, socjologii wartości i norm, jak również o różnych kwestiach pochodnych z tych subdyscyplin socjologicznych.

Po Nocie bibliograficznej znajdujemy też swoiste podsumowanie myśli stanowiących jej treść, jak i próbę oceny merytorycznej i metodologicznej wartości poznawczej i trafności wyboru elementarnych pojęć, problemów i zagadnień socjologii religii, socjologii moralności oraz socjologii wartości i norm, opraco-

\footnotetext{
${ }^{2}$ Zob. J. Szczepański, Elementarne pojęcia socjologii, PWN, Warszawa 1978.
} 
wane przez prof. Uniwersytetu Śląskiego dr. hab. Marka Rembierza, zatytułowane Memoriae causa scripsi. Socjologia do sztambucha, czyli Janusza Mariańskiego ekspresja myśli socjologicznej (ss. 371-408). W spojrzeniu tym nietrudno dostrzec wysoką ocenę wartości i niezbędności tej książki w polskiej socjologii religii i religijności, socjologii moralności, socjologii wartości i norm, z którą trudno byłoby się nie zgodzić, mimo iż została ona zbytnio emocjonalnie ujęta.

Bez wątpienia oceniana książka ks. prof. Janusza Mariańskiego zasługuje na uwagę z kilku następujących powodów: 1) jest ona oryginalnym naukowym dziełem, niespotykanym dotąd w literaturze z zakresu socjologii religii i religijności, socjologii moralności i socjologii wartości i norm, jak i pozostałych zagadnień socjologicznych i humanistycznych; 2) jest ona dziełem opracowanym profesjonalnie pod względem treści poszczególnych rozdziałów, jak i w aspekcie metodologicznym, przez co stanowi ważne źródło wiedzy socjologicznej i wzorów postępowania naukowego dla innych, zwłaszcza młodych, badaczy religijności i moralności ludzi; 3) jest ona typem podręcznika z zakresu wstępu do socjologii religii, moralności i wartości, w którym adepci socjologii i już ukształtowani socjologowie znajdą dobrze zdefiniowane podstawowe pojęcia, problemy i zagadnienia z zakresu tych dziedzin socjologii. Korzystanie z tych pojęć ułatwiłyby zapewne dołączone przypisy wewnętrzne wskazujące dokładnie ich źródło (miejsce, rok i strony), ale zabrakło ich przy omawianiu odautorskim. Wprawdzie na końcu książki Autor wskazuje w nocie bibliograficznej 30 swoich prac, w których znajdują się te pojęcia (aforyzmy, myśli, sentencje i refleksje socjologiczne), jednak one nie ułatwiają pracy własnej (lektury) nad studiowaniem, a tym bardziej przy zastosowaniu ich w innych opracowaniach naukowych, gdzie są wymagane takie przypisy. Publikacje wskazane w nocie bibliograficznej mogą służyć zaledwie jako źródło podręczne; tym bardziej dotyczy to przywoływanych tu przez Autora prac innych socjologów polskich i obcych; 4) została ona napisana zrozumiałym, poprawnym i komunikatywnym językiem socjologicznym, który zachęca do wytrwałej lektury poszczególnych jej części. Zapewne sięgną po nią liczni socjologowie i inni reprezentanci nauk społecznych i humanistycznych zajmujący się religijnością i moralnością ludzi, ich nastawieniem do wartości i norm etycznych. Do lektury tej książki zachęca także estetyczne jej wydanie przez Wyższą Szkołę Nauk Społecznych z siedzibą w Lublinie. 
